\title{
CONCOCTING ULYSSES IN THE NORTH
}

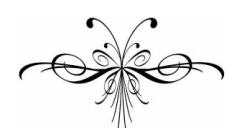

ÁSTRÁĐUR EYSTEINSSON

The first Icelandic publications of works by James Joyce
were translations of two stories from Dubliners ("A Little
Cloud" and "Counterparts") in 1946 and 1961. A third short story, "Eveline" was translated in 1962 by Sigurður A. Magnússon, who later would become the Joyce translator in Iceland, rendering Dubliners as a whole in 1982, Ulysses in 1992-93 (two volumes), and Portrait of the Artist as a Young Man in 2000. ${ }^{2}$

Sigurður A. Magnússon (b. 1928), or SAM as he is sometimes called, is a prolific writer who has had a multifarious career as critic, translator, poet, journalist, editor, columnist, and author of a nine-volume autobiography (the first books of which assume the form of a novel). He is a much-travelled man - a man of many ways, to pick up a phrase used about Odysseus by one of the translators of the Homeric epic into English. ${ }^{3}$ It so happens that Magnússon has been a kind of cultural ambassador of Greece in Iceland. Having spent time in Greece as a young man and learnt Greek, he has translated modern Greek poetry into Icelandic, written three books about Greece, and taken numerous groups of Icelandic visitors on tours to and in Greece. It is somehow appropriate that he should be the one to transfer Joyce's modern Irish odyssey to the even more northerly shores of his native island. In fact, both Ireland and Iceland can be seen as further locations or dwelling points in the Homeric

\footnotetext{
${ }^{1}$ See Ástráður Eysteinsson, "Late Arrivals: James Joyce in Iceland", in The Reception of James Joyce in Europe (Vol. I), ed. Geert Lernout and Wim Van Mierlo (London: Thoemmes Continuum, 2004), pp. 89-102.

2 James Joyce: Í Dyflinni, trans. Sigurður A. Magnússon (Reykjavík: Mál og menning, 1982); ÓdysseifurI-II, trans. Sigurður A. Magnússon (Reykjavík: Mál og menning, 1992-93); Askumynd listamannsins, trans. Sigurður A. Magnússon (Reykjavík: Mál og menning, 2000).

${ }^{3}$ The Odyssey of Homer, trans. Richard Lattimore (New York: Harper \& Row, 1977), p. 27.
} 
adventure - a vital thread in literary history, but more specifically in the literary history of the two islands.

Instead of accepting the Latin "Ulysses" as an international or pan-European designation, Magnússon opted for the Icelandic version of the original Greek as a title for his Icelandic version: Ódysseifur, which for Icelandic readers creates a strong link to the 19th Century Icelandic translation of the Odyssey, that is, Odysseifskviða by Sveinbjörn Egilsson, whose renderings of the Homeric epics are among the most important translations in the Icelandic language.

Odysseus goes from one island to another, and the same is metaphorically true of Leopold Bloom in Ulysses. In the "Lestrygonians", "sandwich passage" under scrutiny in this article, Bloom's island hopping has landed him in Davy Byrne's pub.

The preparation for the Davy Byrne scene is somewhat paradoxical. The reader has just accompanied Bloom on his short visit to Burton restaurant, a visit that echoes the Lestrygonian scene in Homer. That particular island visit in the Odyssey is also short, but decisive: Odysseus's crew has barely arrived when the Lestrygonian giants "speared them like fishes and carried them home for a horrid supper." dismayed and so is Bloom when he views the eating scene in Burton's. "Couldn't eat a morsel here" ( $U$ 8.673), so he decides to go to Davy Byrne's for a "light snack", and the passage might in and by itself serve to convince us that our hero is not only a vegetarian, but a non-carnivore of the sensitive kind, one who suffers for the animals killed for eating purposes: "Slaughter of innocents" (U 8.754).

This, however, is not the Bloom we got to know earlier in the novel. In fact, Bloom is initially introduced to us through his mouth and stomach, as it were, not only gastronomically but unashamedly carnivorously: "Mr Leopold Bloom ate with relish the inner organs of beasts and fowls. He liked thick giblet soup, nutty gizzards, a stuffed roast heart, liverslices fried with crustcrumbs, fried hencods' roes. Most of all he liked grilled mutton kidneys which gave to his palate a fine tang of faintly scented urine" (U 4.1-5).

This stuffed heart, this fine tang - they are still with us in the "Lestrygonians" chapter which from the start has a lot to do with eating, but puts all sorts of twist on the theme, right from "Pineapple rock", through "crossbuns", to the gulls looking for "grub". Bloom feeds them (and the river), first the crumpled "Elijah thirtytwo" and then the Banbury cakes, postponing his own lunch, probably because of what is eating him inside. He is ill at ease, running on empty in more than one sense. "Noone is anything", he thinks. "This is the very worst hour of the day. Vi-

\footnotetext{
${ }^{4}$ Homer: The Odyssey, trans. W.H.D. Rouse (New York: Mentor, n.d.), p. 114.
} 
tality. Dull, gloomy: hate this hour. Feel as if I've been eaten and spewed" (U 8.493-5).

This is of course one more link to the "Lestrygonians" cannibalistic scene in the Odyssey, except that Bloom appears to be inedible: he has been spewed up again, wandering the streets of Dublin as a living dead in some sense, a ghostly figure, like the old Hamlet of the lines that come to his mind as he watches the river, thinking of the "flow of the language" ( $U$ 8.65-68), a flow in which Shakespeare is for Bloom not necessarily so far from those who compose the commercial messages surrounding him. He sees the HELYS men, walking the streets for M'Glade: "His ideas for ads like Plumtree potted under the obituaries, cold meat department" ( $U$ 8.138-9). Given the playful but intense intratextual connections in the novel, sentences like these can be read as preparatory for the sandwich passage. But such threads run throughout the novel; with Bloom we had actually read the Plumtree Potted Meat ad earlier on ( $U$ 5.144-7), and we are still with him when at the end of the day he discovers "an empty pot of Plumtree's potted meat" at home ( $U$ 17.304). But meat has also been potted at 7 Eccles Street in the course of the day, to use the sexual slang Joyce is playing with all along, and the thoughts of this scene have inevitably been disturbing Bloom's inner organs (mind as well as stomach) during his long journey through Dublin.

One cannot but be aware of the manifold connections between food, eating, flesh, death, and sex, and it is this knot that heightens Bloom's sensitivity to the Lestrygonian scene in Burton's, sending him on to Davy Byrne's. There he orders a glass of Burgundy and then his eyes search for something to eat - and so, in his mind, in spite of his momentary aversion to meat, we continue this oesophageal tour of the above elements. Indeed, the tour reaches a kind of climax in the quiet atmosphere of Davy Byrne's - in the sandwich passage that is also part of our tour through Bloom's mind.

The Icelandic translation of Ulysses appears much later than the first translations into several other European languages, and, significantly, it is made after the publication of Hans Walter Gabler's edition, which Magnússon in fact uses as source text (cf. his introduction, p. vii). As a result, Magnússon faces mity cheese, not mighty cheese as he would have had he translated the novel a decade earlier, and which is likely to have resulted in something like máttugi ostur, "powerful cheese". Instead we have sniklaostur, "parasite cheese". Either way, it would be hard to reproduce the Joycean vocal ambivalence of the original, and Magnússon does not try to do so in any roundabout way. So this goes into the list of things "lost in translation": the reader of the translation is perhaps less

\footnotetext{
${ }^{5}$ James Joyce, Ódysseifur (2 vols), trans. Sigurður A. Magnússon (Reykjavík: Mál og menning, 1992), p. 172.
} 
likely to contemplate the critical edge between the powerful and the parasitical, potentially important for our understanding of Bloom, who does in fact go on to order a cheese sandwich.

Due to the "lateness" of the Icelandic version, the first Icelandic translator of Ulysses had access to the results of several decades of Joycean research. In his introduction Magnússon specifically mentions a book that sums up a great deal of textual scrutiny and contextual explanation: Ulysses Annotated by Don Gifford and Robert J. Seidman (the second, expanded, edition from 1988). In his introduction (p. vi), Magnússon notes that if the Icelandic version is more accurate than some earlier translations, for instance the Danish, Swedish or German ones, it is because of the interim appearance of this major key to Joyce's novel. But while this may help pinpoint the problems, it does not necessarily aid the translator in solving them. For instance, Gifford and Seidman (179) explain the joke about Ham the tribal father that Bloom recalls as he observes the ham on offer in the pub. This puts the translator in a very difficult position, and Magnússon has clearly decided to avoid any textual gymnastics in order to recreate the playful ambiguity. He drops Ham and retains the 'ham,' skinka, keeping its descendents, $i$ fríðri fylkingu, 'in proud formation' or 'graceful line-up'. This preserves a fair amount of playfulness and irony, since the formation appears to be made up of potted meats.

Bloom's mental wanderings take him for the second time in this chapter to the Plumtree Potted Meat advertisement he saw in a newspaper that morning, before he went to Paddy Dignam's funeral. This can of meat is a kind of Pandora's box in Bloom's mind, and it opens up in the sandwich passage. Flow of language indeed: he recalls the first three lines of the ad, and the fourth and final line comes later, after the masticated limerick about the royal old nigger and Mr MacTrigger. The ad, which thus reappears as a whole within the sandwich passage, had previously appeared like this in the original (U 5.144-147) and the Icelandic translation:

$$
\begin{aligned}
& \text { What is home without } \\
& \text { Plumtree's Potted Meat? } \\
& \text { Incomplete. } \\
& \text { With it an abode of bliss. } \\
& \text { Hvað er dugleg húsfreyja } \\
& \text { án dósakjöts frá Plumtree? } \\
& \text { Stygg og stúrin afpví } \\
& \text { Í dós er hennar draumur. }
\end{aligned}
$$

The translator has here replaced home with dugleg húsfreyja, 'hard-working housewife', one who gets stygg og stúrin, 'grumpy and 
glum', if she doesn't have a can of Plumtree meat, because her dream is in a can, Í dós er hennar draumur. Under some pressure to adhere to the form and recreate the rhyme, Magnússon has shifted the ad in its relation to Bloom as, on the one hand, an expert reader of ads and, on the other, a vulnerable subject who is clearly strongly hailed and interpellated (in Althusserian terms) by this particular ad. The Plumtree ad assumes relevance for his state of mind and further for the novel's focus on the themes of food, body, sex, marriage and home.

It could be argued that by putting in a 'housewife' instead of 'home', and a 'housewife's dream-in-a-can' instead of 'an abode of bliss', the translator has ignored the way in which Bloom appears to "read himself" and his home into the ad, plus the sex that is and is not taking place there. However, Bloom's thoughts are certainly with his wife, so the translation may not have strayed far off-course. Even though Molly Bloom is hardly a "hardworking housewife" in a traditional sense, the Icelandic version of the ad comes to relate strongly directly to her, with inevitable sexual implications: she is the one who craves that meat; she longs to can the meat of that Plumtree.

Preoccupied as he is with the ad, Bloom still finds it "stupid" and its placement in the newspaper even more so: "Under the obituary notices they stuck it. All up a plumtree. Dignam's potted meat." The adjacency of discourses leads to their metaphoric confluence in Bloom's mind. A body in a coffin is a kind of canned meat - and, yes indeed, it often turns out to be "food" for trees. So "meat" now assumes even more connotative power, and perhaps in order to spare his deceased friend further involvement in this metaphoric complex (or himself the alluring identification with Dignam), Bloom slips the meat into the jungle, so to speak, shifting cannibalistic practices to their alleged tribal context and continuing his train of thoughts there. All of these transfers into Icelandic without too much trouble, but it is interesting to see how Magnússon uses the MacTrigger text to beef up the sexual focus of this whole passage. In Icelandic, the chieftain 'felt' or 'examined', preifaði á, MacTrigger's flesh, 'and then chewed the missionary's muscle.' Thus the translator secures, as it were, the semantic drive of the Plumtree ad implications in a language where the expression 'to pot meat' does not have the sexual message it has in English (or at least had in Irish English at the time) - a message which is important at that particular moment in a Dublin pub, a moment which in Bloom's mind extends far and wide.

When Bloom's thoughts return to the ad, however ("With it an abode of bliss"), Magnússon either fails to notice the recurrence of the Plumtree ad, or he cannot use the fourth line of the ad the way he had originally translated it. Instead we get Paradís á jöro, 'Paradise on Earth', which readers will not recognize as part of the ad but which they may see 
as an indirect reference to the Blooms' home, and the phrase certainly recreates and even strengthens the ironic link between the tribal scene and Bloom's subsequent reflections on the canned meat (the housewife's dream, according to the Icelandic translation).

In the above analysis, the focus has not been so much on elements that the translator has been able to bring across in a "faithfully" equivalent manner, such as rendering "Eat drink and be merry" in a way that echoes the Biblical phrase in Icelandic. More attention has been paid to a number of elements that are "lost" in the process of translating Ulysses into Icelandic, even though, as noted earlier, the novel was translated quite late and the translator had access to major critical sources as well as to translations into other languages. In the sandwich passage, this loss is in a way symbolically reflected in the accidental omission of the word 'sandwich' itself. Bloom's word/question "Sandwich?" is directly translatable into Icelandic as "Samloka?" and yet it is missing from the Icelandic text. Unlike the missing son of Noah, this loss in translation is clearly accidental (and such omissions are unusual in Magnússon's translation, as far as I can tell). It is a little ironic that a translator who is sometimes called SAM should miss both Ham and sam-loka (which literally means 'together-folded' or 'together-closed'), but, on a more serious level, this raises the question of how much loss in translation a work can take without suffering seriously, and whether something possibly "compensates" for such losses.

Loss is traditionally considered a chief flaw of translation, but one must acknowledge, without ignoring the detrimental effect of denotative and connotative losses, that loss is inevitable in translation. In the dynamics of translation, however, loss is part of a larger process, which involves cultural dialogue and a process of rewriting and rearranging that may also involve "compensation" or "gap-fillers", some of which emerge directly and literally from the context. The sandwich may have been lost in Icelandic, but the first thing Bloom says, in English and Icelandic, after the internal monologue of the sandwich passage, is: "Have you a cheese sandwich? / "Eruð pið með ostasamloku?" Cued by this question, the Icelandic reader can assume that Bloom had a sandwich in mind, or at the back of his mind, all along, even though it did not verbally emerge till now.

Further investigation into such and other contextual features would, I believe, establish that while pregnant, dense and knotted modernist passages can be extremely difficult to translate, and while a number of losses may be suffered, such texts are also often semiotically overdetermined, especially when considered in their wider contexts and their intratextual as well as intertextual relations. In other words, they are charged with meaning in such a way as to leave space for the translator, a 
possibility of creating connections to the wider web of the work. I certainly do not mean this to be an apology for bad translation, or even for all of the difficult choices Magnússon had to make in his Ulysses translation, which as a whole is a major achievement in the domain of Icelandic literary practice.

Compensation can be risky business, but it is in fact widely and often successfully practiced in translation. A direct translation of "All up a plumtree" would not make any sense in Icelandic (and the potential connection to Stephen's Parable of the Plums is therefore also lost). Instead Magnússon puts in Útí hött, which colloquially means 'ridiculous' but retains its literal sense of 'into space' or 'into the blue', which is interesting right after the obituary reference and somehow appropriate for Bloom-the-gazer. The sentence "What a stupid ad!" leaves elbow room for the translator. Magnússon has translated it as Pvilik dómadags auglýsing! Now, dómadags is sometimes used as a colloquial prefix in Icelandic to indicate the absurdity of whatever is thus designated, but here also the literal sense emerges. A direct back-translation would give us: "What a Judgment Day ad!" For Bloom it is such an ad, and, in some ways, such a day.

The examples above alert us to the ways in which translation can be, and should be, a creative dialogue between two cultures and between two writers who, to stick to the dietetic and culinary focus of "Lestrygonians", ultimately cook together the meal that readers of translation are served. "Lord knows what concoction", or so it goes in the sandwich passage. The phallic component potentially embedded in the word 'concoction' resonates well in the Icelandic Ulysses: since Magnússon had foregrounded the "missionary's muscle", the fertility member is still with us (even in a state of lack: "Puzzle find the meat") and hardly lost, although not contained in the same way, in the Icelandic word sambras.

Both words, concoction and sambras, constitute vital links between culinary culture and the aesthetics of Ulysses in a broad sense. Joyce's novel is a radical literary concoction of various discourses, methods, and genres. Sambras is something that has been cooked up, literally: 'together-cooked' or 'together-mixed'. Sambras is therefore also what author and translator do together. Thirdly, while thus subsuming the dual authorship of translated works, this concocted word, sam-bras, includes a compressed version of the Icelandic translator's name. This word is without a doubt the centre, if not the heart or some other inner organ, of Ulysses in Icelandic.

Ástráður Eysteinsson
astra@hi.is
University of Iceland 